\title{
STUDI PEMBERIAN PUPUK MAJEMUK DAN CAMPURAN TANAH GAMBUT DENGAN TANAH MINERAL TERHADAP PERTUMBUHAN ANAKAN DURIAN (DURIO MURR)
}

\section{Study of the Provision of Compound Fertilizers and Mixtures of Peat Soils with Mineral Soils Against the Growth of Durian Tiller (Durio Murr)}

\author{
Yos Andy Tangkasiang, ${ }^{1, *}$ \\ ${ }^{1}$ Program Studi Kehutanan, Fakultas Pertanian, Universitas PGRI Palangka Raya, Jl. Hiu \\ Putih - Tjilik Riwut Km 7 Palangka Raya 73112, Kalimantan Tengah, Indonesia *email: \\ yosat66@gmail.com.
}

Studi Pengaruh pupuk mejemuk dan campuran tanah gambut dengan tanah mineral terhadap pertumbuhan anakan Durian (Durio Murr). Tujuannya untuk mengetahui kadar pemberian pupuk majemuk dan perbandingan campuran tanah mineral yang memberikan pengaruh terbaik terhadap pertumbuhan anakan Durian. Waktu yang digunakan selama tiga bulan. Rancangan Acak Lengkap dengan dua faktor. Faktor pertama berupa pupuk majemuk (P) komposisi kandungan N, P dan K $16: 16: 16$. Kadar yang dicobakan ada empat yaitu 0 gram $\left(\mathrm{p}_{0}\right), 1$ gram $\left(\mathrm{p}_{1}\right), 2$ gram $\left(\mathrm{p}_{2}\right)$ dan 3 gram $\left(\mathrm{p}_{3}\right)$ per polybag. Faktor kedua campuran tanah gambut dengan tanah mineral $(\mathrm{T})$ dengan 4 perbandingan : tanpa tanah mineral $+100 \%$ gambut $\left(\mathrm{t}_{0}\right), 5 \%$ tanah mineral $+95 \%$ tanah gambut $\left(\mathrm{t}_{1}\right), 10 \%$ tanah mineral $+90 \%$ tanah gambut $\left(\mathrm{t}_{2}\right), 15 \%$ tanah mineral $+85 \%$ tanah gambut $\left(\mathrm{t}_{3}\right)$. Dari hasil percobaan yang telah dilakukan dapat disimpulkan Pengaruh interaksi tanah mineral dan pupuk majemuk terjadi terhadap pertambahan diameter dan berat basah akar. Terhadap parameter jumlah daun, pertambahan tinggi, berat basah tunas dan berat kering akar, interaksi tidak berbeda nyata. Secara interaksi, pengaruh yang terbaik diberikan oleh $\mathrm{t}_{2} \mathrm{p}_{1}=23,33 \mathrm{~mm}$ terhadap pertambahan diameter. Untuk berat basah akar diberikan oleh $\mathrm{t}_{2} \mathrm{p}_{1}=7,5$ gram. Secara mandiri tanah mineral $5-10 \%$ perpolybag memberikan nilai rata-rata pertumbuhan terbaik terhadap parameter uji. Pupuk majemuk memberikan nilai rata-rata terbaik pada taraf $1-2$ gram pupuk majemuk/polybag.

\section{Kata Kunci : Pertumbuhan Anakan, Pupuk Majemuk, Durio Murr.}

Study of Effect of compound fertilizer and mixture of peat soil with mineral soil on growth of Durian (Durio Murr) tillers. The aim is to determine the levels of compound fertilizer and the comparison of mineral soil mixtures that have the best influence on the growth of Durian tillers. Time used for three months. Complete Random Design with two factors. The first factor is compound fertilizer $(\mathrm{P})$ composition of $\mathrm{N}, \mathrm{P}$ and $\mathrm{K}$ content 16: 16: 16. The levels tested are four, namely 0 gram (p0), 1 gram (p1), 2 gram (p2) and 3 gram (p3) per poly bag. The second factor is the mixture of peat soil with mineral soil $(\mathrm{T})$ with 4 comparisons: without mineral soil $+100 \%$ peat $(\mathrm{t} 0), 5 \%$ mineral soil $+95 \%$ peat soil $(\mathrm{t} 1), 10 \%$ mineral soil $+90 \%$ peat soil ( $\mathrm{t} 2$ ), $15 \%$ mineral soil $+85 \%$ peat soil $(\mathrm{t} 3)$. The results of the experiments that have been conducted can be concluded: The effect of interaction between mineral soil and compound fertilizer only occurs on increasing diameter and root wet weight. The parameters of leaf number, height increase, shoot wet weight and root dry weight, interactions were not significantly different. Interactively, the best effect is given by $t 2 p 1=23.33 \mathrm{~mm}$ on increasing diameter. The root wet weight is given by $\mathrm{t} 2 \mathrm{p} 1=7.5$ grams. Independently mineral 
soil $5-10 \%$ of the polybag provides the best average value of growth against the test parameters. Compound fertilizer provides the best average value at the level of 1-2 grams of compound fertilizer / polybag.

\section{PENDAHULUAN}

Tanaman durian (Durio Murr), disamping buahnya mempunyai nilai ekonomis yang tinggi, dan bisa meningkatkan pendapatan masyarakat di daerah, durian juga berumur panjang dan cocok untuk mencegah erosi karena perakarannya yang kuat, serta tahan terhadap hama dan penyakit.

Untuk ini perlu adanya usaha penelitian yang bertujuan mencari informasi tentang teknik pemacuan pertumbuhan anakan durian sehingga ketersediaan anakan terdapat dalam jumlah yang memadai dengan kualitas anakan yang baik.

Ditinjau dari sifat biologisnya durian jenis yang memiliki siklus pembungaan dan pembuahan yang teratur setiap tahunnya, dan tanaman durian dapat diperbanyak secara generatif (biji) atau secara vegetatif (misalnya okulasi, sambung dan susunan). Namun untuk mendapatkan hasil regenerasi yang baik perlu campur tangan manusia dengan menerapkan teknik-teknik budidaya yang baik karena regenerasi secara alami banyak dipengaruhi oleh kondisi lingkungan yang sering tidak menguntungkan ditambah dengan adanya kegiatan-kegiatan manusia yang dapat merusak lingkungan itu sendiri (Darwin, 1995).

Tanah gambut, dipandang dari sifat fisiknya, mempunyai kandungan bahan yang demikian banyak, dalam klasifikasi tanah gambut termasuk jenis tanah organik. Tanah gambut mempunyai kemampuan untuk menahan dan melewatkan air yang tinggi (sangat pourus) dan mempunyai tingkat kemasaman yang lebih tinggi bila dibandingkan dengan tanah mineral pada kondisi yang sama. Kemampuan menahan air yang tinggi tersebut menjadi sumber ke-masaman atau kandungan $\mathrm{pH}$ rendah.

Dalam hal mengurai kandungan air, tanah gambut dapat dilakukan dengan pengeringan atau pengaliran air. Pengeringan yang berlebihan justru menyebabkan tanah gambut menjadi ringan dan mudah rusak strukturnya sehingga mudah diterbangkan angin serta merusak kemampuan menyerap air. Perbaikan drainase yang bersamaan dengan pengurangan kadar air akan dapat menyebabkan terjadinya pemadatan struktur gambut (Hakim et al, 1986). Pengurangan kadar air tanah gambut sampai pada kadar optimum bagi pertumbuhan tanaman setingkat semai sangat menguntungkan dipandang dari tehnis pengangkutan anakan. 
Berat isi gambut $0,2-0,3$, menyebabkan anakan mudah diangkut beserta media tumbuhnya dalam polybag. Keuntungan dari rendahnya berat isi adalah berat media tumbuh dapat lebih ringan dibandingkan jika menggunakan media tumbuh tanah mineral.

Tanah mineral pada lapisan olah mempunyai berat isi yaitu $1,25-1,45$. Pada prakteknya, berat isi tanah gambut harus mengandung air. Untuk mengurangi sifat dan struktur pourus pada tanah gambut bisa dilakukan dengan penambahan tanah mineral pada kadar tertentu. Tanah mineral mempunyai kemampuan besar dalam menahan air dan tidak mudah kehilangan air, mempunyai peranan sebagai penyerap dan baik dalam pertukaran kation, sehingga unsur hara tersedia bagi tanaman dan terhindar dari bahaya pencucian. (Hakim et al, 1986). Walaupun dinyatakan unsur hara dapat tersedia pada tanah mineral, namun belum tentu hara yang tersedia tersebut ada dalam jumlah yang cukup bagi pertumbuhan dan perkembangan tanaman.

Sehingga perlu ditambahkan unsur hara ke dalam tanah gambut yang diberi campuran tanah mineral sebagai media tumbuh anakan durian dan untuk mengurangi ke-masaman atau menaikkan kadar $\mathrm{pH}$ pada tanah gambut dapat dilakukan dengan pemberian kapur pertanian atau domolit (Indranada, 1994). Berdasarkan uraian di atas, akan diteliti pengaruh pupuk majemuk, campuran tanah gambut dan tanah mineral terhadap pertumbuhan anakan durian. Tujuan dari penelitian ini adalah : untuk mengetahui dosis pupuk majemuk dan perbandingan campuran tanah gambut dengan tanah mineral yang mempunyai pengaruh terbaik terhadap pertumbuhan anakan durian (Durio Murr).

\section{BAHAN DAN METODE}

\section{Rancangan Penelitian}

Penelitian ini merupakan percobaan faktorial dengan Rancangan Acak Lengkap (RAL). Perlakuan menggunakan tiga kali pengulangan. Setiap pengulangan terdiri dari satu unit sampel, dua faktor yang diteliti meliputi Faktor campuran tanah gambut dengan tanah mineral (T) yang terdiri dari 4 (empat) taraf sebagai berikut : $\mathrm{T}_{\mathrm{O}}=100 \%$ tanah gambut, tanpa tanah mineral; $\mathrm{T}_{1}=5 \%$ tanah mineral $+95 \%$ tanah gambut; $\mathrm{T}_{2}=10$ $\%$ tanah mineral $+90 \%$ tanah gambut; $\mathrm{T}_{3}=$ $15 \%$ tanah mineral $+85 \%$ tanah gambut.; Faktor pupuk majemuk (P) yang terdiri dari 4 (empat) taraf sebagai berikut : $\mathrm{P}_{\mathrm{O}}=$ Tanpa pupuk; $\mathrm{P}_{1}=5$ gram pupuk majemuk NPK (setara 3,25 ton/ha); $\mathrm{P}_{2}=10$ gram pupuk majemuk NPK (setara 6,5 ton/ha); $\mathrm{P}_{3}=15$ gram pupuk majemuk NPK (setara 9,75 ton/ha). 


\section{Pelaksanaan}

Penelitian ini dilakukan selama tiga bulan, dari bulan Oktober sampai dengan Desember 2018. Tanah gambut dan tanah mineral dikeringkan dengan cara dijemur dibawah sinar matahari selama satu minggu agar mudah dibersihkan dan diolah, setelah kering tanah gambut dan tanah mineral masingmasing dihaluskan dan di saring untuk mendapatkan butiran yang halus. Kemudian keduanya dicampur sesuai percobaan masing - masing campuran seberat 2 kg. Setelah pencampuran, dua jenis tanah tersebut diberi kapur dolamit dengan takaran masing-masing 2,5 gram per $2 \mathrm{~kg}$ media tumbuh, sesudah itu di masukkan ke dalam polybag dan di basahkan kembali dengan air. Kemudian di tempatkan di bedengan semai tetapi dibiarkan (inkubasi) selama 7 hari untuk oksidasi kapur dolomit.

Satu hari sebelum masa inkubasi selesai dilakukan pemberian perlakuan pupuk NPK majemuk untuk masing-masing perlakuan sesuai dengan dosis yang telah ditentukan. Setelah masa inkubasi berakhir di laksanakan penanaman anakan durian satu anakan per polybag. Anakan durian yang telah diambil dari persemaian di lepas dari polybag semai dan media tumbuhnya perlahan-lahan. Media tumbuh asal diusahakan tidak seluruhnya dibuang terutama yang berada sekitar tudung dan bulu

akar. Sesudah dimasukkan, baru di tutupi kembali dengan media tumbuh pada bagian atas dalam polybag penelitian. Pemeliharaan yang diberikan berupa penyiraman setiap pagi dan sore hari serta pembersihan dari rumput yang tumbuh di sekitar dan dalam bedengan semai atau dalam polybag. Untuk menghindarkan serangan hama insekta, diberikan larutan Thiodan 40 EC dengan dosis $2 \mathrm{ml} / \mathrm{liter}$ air dengan cara menyemprokannya ke daun anakan durian (Durio Murr) dengan interval 2 minggu sekali.

Pengamatan dilakukan setiap dua minggu sekali terhadap. Khusus pengamatan bobot basah akar dan bobot kering akar dilakukan pada akhir percobaan. Parameter yang diamati pertambahan jumlah daun tunas, pertambahan tinggi tunas semai, pertambahan diameter tunas, bobot basah tunas, bobot basah akar, bobot kering akar telah dikeringkan.

\section{Analisa Data}

Data yang diperoleh pada setiap perlakuan di hitung rata-ratanya, selanjutnya, di lakukan analisa ragam untuk mengetahui pengaruh interaksi antara campuran tanah gambut dengan tanah mineral dan pupuk majemuk terhadap semua parameter yang di amati. Bilamana interaksi berpengaruh maka selanjutnya dicari perlakuan mana yang 
paling berpengaruh dengan menggunakan uji beda.

\section{HASIL DAN PEMBAHASAN}

\section{HASIL}

Hasil penelitian dapat di lihat dalam bentuk tabel yang disajikan pada tabel 1 sampai dengan tabel 10. Pertambahan Jumlah Daun menunjukkan interaksi pengaruh yang tidak nyata. Jika dilihat dari

Tabel 1. Uji beda nilai rata-rata pengaruh tanah mineral terhadap pertambahan jumlah daun (helai).

\begin{tabular}{|c|c|c|}
\hline Tanah Mineral & Nilai Rata-rata & (helai) \\
\hline $\mathrm{t}_{\mathrm{o}}$ & 2,25 & $\mathrm{a}$ \\
\hline $\mathrm{t}_{3}$ & 3,50 & $\mathrm{~b}$ \\
\hline $\mathrm{t}_{1}$ & 4,00 & $\mathrm{~b}$ \\
\hline $\mathrm{t}_{2}$ & 4,33 & $\mathrm{~b}$ \\
\hline
\end{tabular}

Keterangan: Angka-angka yang diikuti oleh huruf dan pada kolom yang sama berarti berbeda tidak nyata pada $\mathrm{P} 0,05$.

\section{Pertambahan Tinggi Anakan Durian.}

Analisa ragam dilakukan terhadap data pertambahan tinggi anakan menunjukkan interaksi tidak berpengaruh nyata terhadap pertambahan tinggi anakan. Jika dilihat dari faktor tunggalnya, baik pupuk majemuk maupun campuran tanah gambut dengan tanah mineral masing-masing memberikan pengaruh sangat nyata. Sama halnya dengan uji lanjutan yang diberikan terhadap data jumlah daun, tidak dilakukan uji beda terhadap nilai rata-rata pengaruh interaksi. Uji beda dilakukan terhadap masing-masing faktor tunggalnya masing - masing pupuk majemuk dan campuran tanah gambut dengan tanah mineral berpengaruh sangat nyata. Uji beda terhadap interaksi tidak dilakukan hanya dilakukan terhadap masingmasing nilai rata-rata pengaruh faktor tunggal sebagaimana Tabel 1 dan Tabel 2.

Tabel 2. Uji beda nilai rata-rata pengaruh pupuk majemuk terhadap pertambahan jumlah daun (helai).

\begin{tabular}{|c|c|c|}
\hline Pupuk Majemuk & $\begin{array}{r}\text { Nilai Rata- } \\
\text { rata }\end{array}$ & (helai) \\
\hline $\mathrm{p}_{\mathrm{o}}$ & 2,50 & $\mathrm{a}$ \\
\hline $\mathrm{p}_{3}$ & 3,00 & $\mathrm{a}$ \\
\hline $\mathrm{p}_{1}$ & 4,17 & $\mathrm{~b}$ \\
\hline $\mathrm{p}_{2}$ & 4,42 & $\mathrm{~b}$ \\
\hline
\end{tabular}

Keterangan: Angka-angka yang diikuti oleh huruf dan pada kolom yang sama berarti berbeda tidak nyata pada $\mathrm{P} 0,05$.

nilai rata-rata pengaruh faktor tunggal sebagaimana Tabel 3 dan Tabel 4.

Tabel 4. Uji beda nilai rata-rata pengaruh pupuk majemuk terhadap pertambahan tinggi anakan $(\mathrm{cm})$.

Tabel 3. Uji beda nilai rata-rata pengaruh tanah mineral terhadap pertambahan tinggi anakan $\operatorname{Durian}(\mathrm{cm})$.

\begin{tabular}{|c|c|c|}
\hline Tanah Mineral & Rata & $(\mathrm{cm})$ \\
\hline $\mathrm{t}_{\mathrm{o}}$ & 3,30 & $\mathrm{a}$ \\
\hline $\mathrm{t}_{1}$ & 5,82 & $\mathrm{~b}$ \\
\hline $\mathrm{t}_{3}$ & 6,23 & $\mathrm{~b}$ \\
\hline $\mathrm{t}_{2}$ & 6,40 & $\mathrm{~b}$ \\
\hline
\end{tabular}


Keterangan: Angka-angka yang diikuti oleh huruf dan pada kolom yang sama berarti berbeda tidak nyata pada $\mathrm{P} 0,05$.

\begin{tabular}{|c|c|c|}
\hline $\begin{array}{c}\text { Pupuk } \\
\text { Majemuk }\end{array}$ & Rata-rata & $(\mathrm{cm})$ \\
\hline $\mathrm{p}_{\mathrm{o}}$ & 3,76 & $\mathrm{a}$ \\
\hline $\mathrm{p}_{1}$ & 5,38 & $\mathrm{~b}$ \\
\hline $\mathrm{p}_{3}$ & 6,23 & $\mathrm{c}$ \\
\hline $\mathrm{p}_{2}$ & 6,36 & $\mathrm{c}$ \\
\hline
\end{tabular}

Keterangan: Angka-angka yang diikuti oleh huruf dan pada kolom yang sama berarti berbeda tidak nyata pada $\mathrm{P} 0,05$.

\section{Pertambahan Diameter}

Analisa ragam dilakukan pada data pertambahan diameter batang menunjukkan interaksi berpengaruh nyata terhadap pertambahan diameter anakan durian. Demikian pula kedua faktor tunggal, campuran tanah gambut dengan tanah mineral dan pupuk majemuk. Untuk mengetahui perlakuan mana yang terbaik, dilakukan uji beda terhadap nilai rata-rata pengaruh interaksi sebagaimana hasilnya pada Tabel 5.

Tabel 5. Uji beda nilai rata-rata pengaruh interaksi terhadap pertambahan diameter anakan Durian (mm).

\begin{tabular}{|c|c|c|}
\hline Perlakuan & Rata-rata & $\begin{array}{c}\text { diameter } \\
(\mathrm{mm})\end{array}$ \\
\hline $\mathrm{t}_{1} \mathrm{p}_{1}$ & 1,00 & $\mathrm{a}$ \\
\hline $\mathrm{t}_{0} \mathrm{p}_{0}$ & 1,17 & $\mathrm{~b}$ \\
\hline $\mathrm{t}_{0} \mathrm{p}_{1}$ & 1,17 & $\mathrm{~b}$ \\
\hline $\mathrm{t}_{1} \mathrm{p}_{0}$ & 1,17 & $\mathrm{~b}$ \\
\hline $\mathrm{t}_{2} \mathrm{p}_{0}$ & 1,17 & $\mathrm{~b}$ \\
\hline $\mathrm{t}_{3} \mathrm{p}_{0}$ & 1,17 & $\mathrm{~b}$ \\
\hline $\mathrm{t}_{0} \mathrm{p}_{3}$ & 1,33 & $\mathrm{c}$ \\
\hline $\mathrm{t}_{1} \mathrm{p}_{2}$ & 1,50 & $\mathrm{~d}$ \\
\hline $\mathrm{t}_{3} \mathrm{p}_{2}$ & 1,50 & $\mathrm{~d}$ \\
\hline $\mathrm{t}_{0} \mathrm{p}_{2}$ & 1,67 & $\mathrm{e}$ \\
\hline $\mathrm{t}_{0} \mathrm{p}_{3}$ & 1,67 & $\mathrm{e}$ \\
\hline $\mathrm{t}_{3} \mathrm{p}_{1}$ & 1,67 & $\mathrm{e}$ \\
\hline
\end{tabular}

\begin{tabular}{|l|l|l|}
\hline $\mathrm{t}_{3} \mathrm{p}_{3}$ & 1,67 & $\mathrm{e}$ \\
\hline $\mathrm{t}_{2} \mathrm{p}_{3}$ & 2,00 & $\mathrm{f}$ \\
\hline $\mathrm{t}_{2} \mathrm{p}_{1}$ & 2,33 & $\mathrm{~g}$ \\
\hline $\mathrm{t}_{2} \mathrm{p}_{2}$ & 2,33 & $\mathrm{~g}$ \\
\hline
\end{tabular}

Keterangan: Angka-angka yang diikuti oleh huruf dan pada kolom yang sama berarti berbeda tidak nyata pada $\mathrm{P} 0,05$.

\section{Bobot Basah Tunas.}

Analisa ragam terhadap data bobot basah tunas menunjukkan bahwa interaksi tidak bepengaruh terhadap bobot basah tunas anakan Durian (Durio Murr). Dilihat dari faktor pupuk majemuk dan campuran tanah gambut dengan tanah mineral berpengaruh sangat nyata. Uji beda terhadap dilakukan terhadap masing-masing nilai rata-rata pengaruh faktor tunggal sebagaimana Tabel 6 dan Tabel 7.

Tabel 6. Uji beda nilai rata-rata pengaruh tanah mineral terhadap bobot kering anakan Durian (gram).

\begin{tabular}{|c|c|c|}
\hline Tanah Mineral & \multicolumn{2}{|c|}{ Nilai Rata-rata } \\
\hline $\mathrm{t}_{\mathrm{o}}$ & 21,94 & $\mathrm{a}$ \\
\hline $\mathrm{t}_{3}$ & 22,10 & $\mathrm{a}$ \\
\hline $\mathrm{t}_{1}$ & 25,29 & $\mathrm{~b}$ \\
\hline $\mathrm{t}_{2}$ & 27,03 & $\mathrm{~b}$ \\
\hline
\end{tabular}

Keterangan: Angka-angka yang diikuti oleh huruf dan pada kolom yang sama berarti berbeda tidak nyata pada $\mathrm{P} 0,05$.

Tabel 7. Uji beda nilai rata-rata pengaruh pupuk majemuk terhadap bobot basah tunas anakan Durian (gram).

\begin{tabular}{|c|c|c|}
\hline $\begin{array}{c}\text { Pupuk } \\
\text { Majemuk }\end{array}$ & $\begin{array}{c}\text { Nilai Rata- } \\
\text { rata }\end{array}$ & (gram) \\
\hline
\end{tabular}




\begin{tabular}{|c|c|c|}
\hline $\mathrm{p}_{\mathrm{o}}$ & 21,94 & $\mathrm{a}$ \\
\hline $\mathrm{p}_{3}$ & 22,10 & $\mathrm{~b}$ \\
\hline $\mathrm{p}_{1}$ & 25,29 & $\mathrm{bc}$ \\
\hline $\mathrm{p}_{2}$ & 27,03 & $\mathrm{c}$ \\
\hline
\end{tabular}

Keterangan: Angka-angka yang diikuti oleh huruf dan pada kolom yang sama berarti berbeda tidak nyata pada $\mathrm{P} 0,05$.

\section{Bobot Basah Akar.}

Analisa ragam bobot basah akar menunjukkan bahwa interaksi bepengaruh sangat nyata terhadap bobot basah akar anakan Durian (Durio Murr). Demikian pula masing-masing faktor tunggal; tanah mineral dan pupuk majemuk; dan interaksi kedua faktor tunggal tersebut. Uji beda dilakukan terhadap nilai rata - rata pengaruh interaksi sebagaimana Tabel 8.

Tabel 8. Uji beda nilai rata-rata pengaruh interaksi terhadap bobot basah akar anakan Durian (gram).

\begin{tabular}{|c|c|c|}
\hline Perlakuan & Rata-rata & (gram) \\
\hline $\mathrm{t}_{0} \mathrm{p}_{3}$ & 3,50 & $\mathrm{~A}$ \\
\hline $\mathrm{t}_{3} \mathrm{p}_{0}$ & 4,03 & $\mathrm{Ab}$ \\
\hline $\mathrm{t}_{0} \mathrm{p}_{2}$ & 4,03 & $\mathrm{Ab}$ \\
\hline $\mathrm{t}_{1} \mathrm{p}_{0}$ & 4,30 & $\mathrm{Abc}$ \\
\hline $\mathrm{t}_{0} \mathrm{p}_{0}$ & 4,73 & $\mathrm{Abc}$ \\
\hline $\mathrm{t}_{1} \mathrm{p}_{3}$ & 4,73 & $\mathrm{Abc}$ \\
\hline $\mathrm{t}_{2} \mathrm{p}_{3}$ & 5,00 & $\mathrm{Abcd}$ \\
\hline $\mathrm{t}_{2} \mathrm{p}_{1}$ & 5,20 & $\mathrm{Bcd}$ \\
\hline $\mathrm{t}_{3} \mathrm{p}_{3}$ & 5,20 & $\mathrm{Bcd}$ \\
\hline $\mathrm{t}_{0} \mathrm{p}_{1}$ & 5,43 & $\mathrm{Bcd}$ \\
\hline $\mathrm{t}_{1} \mathrm{p}_{2}$ & 5,43 & $\mathrm{Bcd}$ \\
\hline $\mathrm{t}_{3} \mathrm{p}_{1}$ & 5,67 & $\mathrm{Cd}$ \\
\hline $\mathrm{t}_{1} \mathrm{p}_{1}$ & 6,40 & $\mathrm{De}$ \\
\hline $\mathrm{t}_{3} \mathrm{p}_{2}$ & 7,27 & $\mathrm{Ef}$ \\
\hline $\mathrm{t}_{2} \mathrm{p}_{1}$ & 7,50 & $\mathrm{Ef}$ \\
\hline $\mathrm{t}_{2} \mathrm{p}_{2}$ & 8,33 & $\mathrm{~F}$ \\
\hline
\end{tabular}

Keterangan: Angka-angka yang diikuti oleh huruf dan pada kolom yang sama berarti berbeda tidak nyata pada $\mathrm{P} 0,05$.

\section{Bobot Kering Akar.}

Analisa ragam terhadap data bobot kering akar menunjukkan bahwa interaksi tidak bepengaruh terhadap berat kering akar, demikian pula masing-masing faktor tunggal; pupuk majemuk dan campuran tanah gambut dengan tanah mineral. Uji beda dilakukan terhadap nilai rata-rata masing - masing pengaruh faktor tunggal sebagaimana Tabel 9 dan Tabel 10.

Tabel 9. Uji beda nilai rata-rata pengaruh tanah mineral terhadap bobot kering akar anakan Durian (gram).

\begin{tabular}{|c|c|c|}
\hline Tanah Mineral & Nilai Rata-rata & (gram) \\
\hline $\mathrm{t}_{\mathrm{o}}$ & 2,30 & $\mathrm{a}$ \\
\hline $\mathrm{t}_{3}$ & 2,54 & $\mathrm{ab}$ \\
\hline $\mathrm{t}_{1}$ & 2,95 & $\mathrm{bc}$ \\
\hline $\mathrm{t}_{2}$ & 3,43 & $\mathrm{c}$ \\
\hline
\end{tabular}

Keterangan: Angka-angka yang diikuti oleh huruf dan pada kolom yang sama berarti berbeda tidak nyata pada $\mathrm{P} 0,05$.

Tabel 10. Uji beda nilai rata-rata pengaruh pupuk majemuk terhadap bobot kering akar anakan Durian.

\begin{tabular}{|c|c|c|}
\hline Pupuk Majemuk & Nilai Rata-rata & (gram) \\
\hline $\mathrm{p}_{\mathrm{o}}$ & 2,38 & $\mathrm{a}$ \\
\hline $\mathrm{P}_{3}$ & 2,44 & $\mathrm{a}$ \\
\hline $\mathrm{P}_{1}$ & 3,18 & $\mathrm{~b}$ \\
\hline $\mathrm{p}_{2}$ & 3,20 & $\mathrm{~b}$ \\
\hline
\end{tabular}

Keterangan: Angka-angka yang diikuti oleh huruf dan pada kolom yang sama berarti berbeda tidak nyata pada $\mathrm{P} 0,05$.

\section{PEMBAHASAN}

\section{Pertambahan Jumlah Daun}

Kombinasi perlakuan antara tanah mineral dengan pupuk majemuk diketahui 
tidak berpengaruh nyata terhadap tanah mineral/polybag) yaitu 4,0 helai. pertambahan bahan jumlah daun anakan Walaupun nilai rata-rata pengaruh $\mathrm{t}_{2}$ terbesar Durian (Durio Murr). Dilihat dari data yang namun tidak berbeda nyata dengan $\mathrm{t}_{1}$ bahkan ada, terdapat kecenderungan jumlah daun berbeda antara satu kombinasi lainnya. Diduga, kedua faktor tersebut saling berinteraksi satu sama lain namun interaksi tersebut sangat lemah sehingga tidak dapat mempengaruhi pertambahan jumlah daun secara nyata. Pemberian tanah mineral dapat mempengaruhi sifat fisik media tumbuh sehingga memungkinkan perkembangan akar cenderung terhambat. Semakin banyak akar semakin banyak pula unsur hara yang diserap dalam kondisi lingkungan yang sesuai.

Perkembangan akar yang terbatas menyebabkan penyerapan unsur hara yang terbatas pula. Pengaruh yang diberikan oleh tanah mineral dan pupuk majemuk terhadap pertambahan jumlah daun lebih kuat jika dilihat dari segi kemandirian masing-masing faktor tersebut. Faktor tanah mineral memberikan pengaruh terhadap pertambahan jumlah daun dengan nilai rata-rata tertinggi 4,33 helai yang dihasilkan oleh $\mathrm{t}_{2}(10 \%$ tanah mineral/polybag). Nilai rata-rata tersebut nilai yang berbeda nyata dengan $\mathrm{t}_{0}(0$ $\%$ tanah mineral/polybag), tidak berbeda nyata dengan nilai rata-rata $t_{3}(15 \%$ tanah mineral/polybag) yaitu 3,50 helai, juga tidak berbeda nyata dengan nilai rata-rata $t_{1}(5 \%$ $\mathrm{t}_{1}$ sendiri lebih tinggi dari $\mathrm{t}_{3}$, maka nilai ratarta pertambahan jumlah daun yang terbaik adalah 4,0 helai yang dihasilkan oleh $\mathrm{t}_{1}$. karena nilai $t_{1}$ dari $t_{3}$ dan tidak berbeda nyata dengan $t_{2}$, serta secara tehnis cukup dengan memberikan tanah mineral $5 \%$ perpolybag, telah dapat mencapai nilai yang dihasilkan oleh $t_{2}$.

Pupuk majemuk berpengaruh nyata terhadap pertambahan jumlah daun, nilai rata-rata tertinggi dihasilkan oleh $\mathrm{p}_{2}$ (2 gram pupuk majemuk/polybag) yaitu 4,42 helai, namun tidak berbeda nyata dengan nilai ratarata $\mathrm{p}_{1}$ (1 gram pupuk majemuk/polybag yaitu 4,17 helai. Baik $\mathrm{p}_{1}$ dan $\mathrm{p}_{2}$ berbeda sangat nyata terhadap $\mathrm{p}_{0}$ (0 gram pupuk majemuk/polybag) yaitu 2,5 helai dan $\mathrm{p}_{3}$ (3 gram pupuk majemuk/polybag) yaitu 3,0 helai. Nilai rata-rata terbaik dalam hal ini dihasilkan oleh $\mathrm{p}_{1}$, karena cukup dengan memberikan pupuk majemuk 1 gram/polybag dapat menghasilkan nilai rata-rata yang tidak berbeda nyata dengan nilai rata-rata yang tidak berbeda nyata dengan nilai yang dihasilkan oleh $\mathrm{t}_{2 .}$.

\section{Pertambahan Tinggi.}

Pemberian tanah mineral dan pupuk majemuk ternyata tidak berinteraksi dalam 
mempengaruhi pertambahan tinggi anakan durian. Meskipun pengaruh itu ada, diduga sangat lemah sehingga secara statistik tidak terdapat interaksi. Data yang ada menunjukkan bahwa setiap kombinasi kedua faktor tunggal tersebut mempunyai nilai pertambahan tinggi yang berbeda satu sama lain. Hal dimungkinkan kurangnya dosis yang diberikan. Pertambahan tinggi tersebut nyata jika dilihat secara mandiri untuk masing-masing faktor. Tanah mineral mempunyai $F$ hitung yang lebih besar daripada $f$ tabel, yang berarti pengaruh tanah mineral sangat nyata terhadap pertambahan tinggi anakan durian.

Nilai pertambahan tinggi tertinggi dihasilkan oleh $\mathrm{t}_{2} \quad(10 \quad \% \quad$ tanah mineral/polybag) yaitu $6,4 \mathrm{~cm}$, tetapi tidak berbeda nyata dengan nilai rata-rata yang dihasilkan oleh $\mathrm{t}_{3} \quad(15 \quad \% \quad$ tanah mineral/polybag) yaitu $6,23 \mathrm{~cm}$ dan juga $\mathrm{t}_{2}$ tersebut tidak berbeda nyata dengan $\mathrm{t}_{1}(5 \%$ tanah mineral/polybag) yaitu $5,82 \mathrm{~cm}$. Sehingga nilai rata-rata terbaik adalah 5,82 dtersebut yang dihasilkan oleh taraf tanah mineral $\left(\mathrm{t}_{1}\right)$. Hal ini dimungkinkan adanya kecukupan unsur yang diberikan bagi tanaman. Pupuk juga berpengaruh nyata terhadap pertambahan tinggi anakan durian, $\mathrm{p}_{2}$ (2 gram pupuk majemuk/polybag) menghasilkan nilai tertinggi yaitu $6,36 \mathrm{~cm}$.
Sedangkan $\quad \mathrm{p}_{3} \quad(3 \quad$ gram pupuk majemuk/polybag) memberikan nilai ratarata sebesar $6,23 \mathrm{~cm}$, lebih rendah dari nilai rata-rata $\mathrm{p}_{1}$. antara kedua nilai rata-rata tersebut tidak berbeda nyata, hal ini dikarenakan sedikitnya unsur pupuk yang diberikan, tetapi kedua nilai rata-rata tersebut tidak berbeda nyata terhadap nilai rata-rata yang diberikan oleh $\mathrm{p}_{0}$ (0 gram pupuk majemuk/polybag) dan $\mathrm{p}_{1}$ (1 gram pupuk majemuk/polybag) masing-maing $3,76 \mathrm{~cm}$ dan $5,58 \mathrm{~cm}$ dalam hal ini taraf pemberian pupuk $\mathrm{p}_{2}$ merupakan taraf perlakuan terbaik karena mempunyai nilai rata-rata tertinggi.

Dengan 2 gram pupuk majemuk/polybag dapat memberikan nilai rata-rata pertambahan tinggi yang lebih tinggi dari taraf perlakuan pupuk majemuk $\mathrm{p}_{3}$.

Dari uraian diatas diketahui bahwa ternyata untuk pertambahan tinggi, tanaman memerlukan pupuk majemuk yang lebih banyak daripada pertumbuhan atau pertambahan daun. Diduga hal ini terjadi karena perkembanngan daun akan sangat lambat jika luas daun maksimal telah tercapai bahkan dapat tehambat karena luas perkembangan daun yang terbatas. Sedangkan pertumbuhan meninggi akan terus berlangsung sampai batas waktu yang lebih lama daripada perkembangan daun, yaitu sampai tanaman mencapai batas tinggi 
maksimum. Pupuk yang digunakan lebih banyak mengingat setelah digunakan untuk pertumbuhan dan perkembangan daun, maka daun akan memerlukan pupuk lebih banyak untuk proses menjadi karbohidrat yang di suplai ke batang dan bagian lain dari tanaman.

\section{Pertambahan Diameter.}

Perlakuan pemberian tanah mineral dan pupuk majemuk ternyata berinteraksi yang nyata dalam mempengaruhi pertambahan diameter anakan durian. Hal ini diketahui dari nilai $\mathrm{F}$ hitung yang lebih besar dari $\mathrm{F}$ tabel. Diduga, kondisi media tumbuh yang berupa tanah gambut dan tanah mineral yang diberi pupuk majemuk yang tidak kuat pengaruhnya terhadap pertambahan jumlah daun dan pertambahan tinggi anakan Durian (sebagai mana dibahas terlebih dahulu, lebih kuat pengaruhnya terhadap pertambahan diameter, mengingat pertambahan sangat kecil, rata-rata $1,53 \mathrm{~mm}$. Uji beda yang dilakukan terhadap nilai rata-rata pertambahan diameter menunjukkan $\mathrm{t}_{2} \mathrm{p}_{2}(10$ $\%$ tanah mineral dan 2 gram pupuk majemuk/polybag), mempunyai nilai tertinggi $23,33 \mathrm{~mm}$ sama dengan yang dihasilkan $\mathrm{t}_{2} \mathrm{p}_{1}(10 \%$ tanah mineral dan 1 gram pupuk majemuk/polybag) yaitu 23,33 $\mathrm{mm}$.
Dari nilai tersebut, diketahui bahwa kedua kombinasi perlakuan tersebut mempunyai nilai yang tidak berbeda nyata satu sama lain, namun sama-sama berbeda sangat nyata dengan nilai rata-rata yang dihasilkan oleh kombinasi perlakuan lain. Jadi 23,33 $\mathrm{mm}$ merupakan angka tertinggi yang dihasilkan oleh $t_{2} p_{1}$ dan $t_{2} p_{2}$. Untuk efisiensi penggunaan pupuk $t_{2} p_{i}$ merupakan terbaik. Karena hanya dengan memberikan pupuk majemuk 1 gram / polybag pada pencampuran tanah mineral $10 \%$ terhadap tanah gambut per polybagnya, telah dapat mencapai nilai rata-rata yang dihasilkan oleh $\mathrm{t}_{2} \mathrm{p}_{2}$, artinya sudah bisa mencukupi akan kebutuhan unsur yang diperlukan.

\section{Bobot Basah Tunas.}

Tidak terdapat interaksi nyata antara mineral dan pupuk majemuk dalam mempengaruhi bobot basah tunas. Diduga tidak terjadi kondisi media tumbuh yang sesuai untuk dapat terjadinya interaksi tersebut. Secara faktor tunggal terdapat pengaruh nyata pupuk majemuk dan pengaruh nyata campuran tanah gambut dengan tanah mineral terhadap bobot basah tunas. Tanpa tanah mineral $t_{0}$ berat basah tunas ada dalam keadaan rendah, nilai rataratanya 21,44 gram. Berat basah tertinggi dihasilkan oleh $\mathrm{t}_{2} \quad(10 \quad \% \quad$ tanah mineral/polybag) yaitu 27,03 gram, $\mathrm{t}_{3}(15 \%$ 
tanah mineral/polybag) dan $\mathrm{t}_{1}(5 \%$ tanah mineral/polybag) masing-masing 22,10 dan 25,29 gram. Taraf $t_{0}$ mempunyai berat basah yang paling rendah. Diduga sifat fisik tanah gambut yang gembur dan berada dalam polybag, dapat memperlancar proses keluarnya air dari media tumbuh.

Dari segi kuantitas akar, tanah gambut tanpa tanah mineral mempunyai kemasaman yang tinggi sehingga menghambat penyerapan unsur hara lebih sedikit yang pada akhirnya mengurangi pertumbuhan dan perkembangan tunas. Nilai tertinggi dihasilkan oleh $\mathrm{t}_{2}$ dimana kondisi media tumbuh lebih memberikan keluasaan bagi akar untuk menyerap air.

\section{Bobot Basah Akar.}

Terhadap berat basah akar ternyata terjadi interaksi antara tanah mineral dan pupuk majemuk dalam mempengaruhi bobot basah akar. Diduga hal ini terjadi tanah mineral yang diberikan mampu menyediakan kondisi yang baik bagi akar terutama untuk penyerapan air sehingga akan lebih aktif menyerap hara yang diberikan. Nilai rata-rata interaksi tetinggi dihasilkan antara pencampuran tanah mineral $10 \%$ perpolybag sebesar 8,33 gram. Nilai tersebut berbeda nyata dengan nilai rata-rata perlakuan lain, kecuali berbeda tidak nyata dengan nilai ratarata yang dihasilakn oleh $t_{2} p_{2}$ yaitu 7,5 gram dan dengan nilai yang dihasilkan oleh $\mathrm{t}_{3} \mathrm{p}_{2}$ tetapi kandungan tanah mineral $\mathrm{t}_{3} \mathrm{p}_{2}$ terlalu besar dan pupuk 2 gram perpolybag. Demikain pula halnya, walaupun tidak berbeda nyata dengan $t_{2} p_{1}$, tetapi $t_{2} p_{2}$ sendiri mempunyai konsentrasi pupuk yang tinggi. Oleh sebab itu nilai rata-rata yang terbaik dalam hal ini dihasilkan oleh $\mathrm{t}_{2} \mathrm{p}_{1}$. karena hanya $t_{2}(10 \%$ tanah mineral $)$ dan $\mathrm{p}_{1}$ (1 gram pupuk majemuk ) telah mampu menghasilkan nilai yang tidak berbeda nyata dengan nilai rata-rata yang dihasilkan oleh $t_{3} p_{2}$ dan $t_{2} p_{2}$, artinya sudah bisa mencukupi akan kebutuhan unsur yang diperlukan.

\section{Bobot Kering Akar.}

Bobot kering akar ternyata tidak diengaruhi oleh interaksi tanah mineral dan pupuk majemuk. Hanya secara mandiri masing-masing faktor tunggal tersebut mempengaruhi bobot kering akar. Diduga, hal ini terjadi oleh lemahnya interaksi yang terjadi sehngga pengaruh interaksi yang terjadi sehingga interaksi tidak nyata. Interaksi tanah mineral dan pupuk majemuk yang mampu mempengaruhi bobot basah akar secara nyata, ternyata tidak mampu mempungaruhi berat kering akar dalam kondisi yang ada air. Air yang terdapat pada akar bersifat sementara dan tidak mempengaruhi perbanyakan produksi sel sel akar anakan Durian. 


\section{SIMPULAN}

Dari hasil dan pembahasan dapat disimpulkan:

1. Interaksi antara tanah mineral dan pupuk majemuk berpengaruh hanya terhadap pertambahan diameter dan berat basah akar. Namun interaksi tidak berbeda nyata untuk parameter jumlah daun, pertambahan tinggi, berat basah tunas, dan berat kering akar,.

2. Pengaruh secara interaksi yang terbaik diberikan oleh kombinasi $\mathrm{t}_{2} \mathrm{p}_{1}$, sebesar $=$ 23,33 $\mathrm{mm}$ terhadap pertambahan diameter, sedangkan untuk berat basah akar diberikan oleh kombinasi $\mathrm{t}_{2} \mathrm{p}_{1}$, sebesar $=7,5$ gram.

3. Pengaruh pemberian tanah mineral $5-10$ $\% /$ polybag secara mandiri memberikan nilai rata-rata pertumbuhan terbaik terhadap parameter uji, untuk pupuk majemuk ternyata memberikan nilai ratarata terbaik pada taraf $1-2$ gram pupuk majemuk/polybag.

\section{DAFTAR PUSTAKA}

1985. Dendrologi. Bahan Kuliah Fakultas Kehutanan Unlam Banjarbaru. Banjarbaru.

1992. Manual Kehutanan. Departemen Kehutanan Republik Indonesia. Jakarta.
, 1996. Budidaya Durian, AKKSPP Kanisius Ambarawa, Kanisius, Yogyakarta. , 2005. Panduan Kehutanan, Direktorat Hutan Tanaman Industri (HTI). Departemen Kehutanan Republik. Jakarta.

2005. Website,

Indonesianforest. Departemen

Kehutanan Republik Indonesia. Jakarta.

Buckman. H.O \& Brady Nyle. C. 1982. Ilmu

Tanah. Bhratara Karya Aksara. Jakarta.

Darmawijaya, M. Isa, 1990. Klasifikasi Tanah. Gadjah Mada Universitas Press. Yogyakarta.

Haeruman, Herman, 1972. Pedoman Analisis Rancangan Percobaan Bagian I. Bagian Rancangan Hutan, Departemen Manajemen Hutan, Fakultas Kehutanan IPB. Bogor.

Hakim, Nurhayati., M. Yusuf Nyakpa, A.M. Lubis, Sutopo Ghani Nugroho, M. Rusdi Saul, M. Amin Diha, Go Ban Hong, dan H.H. Bailey, 1986. Dasardasar Ilmu Tanah. Universitas Lampung.

Hanafiah, Kemas Ali, 1993. Rancangan Percobaan. Fakultas Pertanian Universitas Sriwijaya. Palembang.

Hardjowigeno S. 2003. Ilmu Tanah. Akademika Pressindo, Jakarta.

Indranada, 1994. Kapur Dolomit Untuk Pertanian Pada Tanah Gambut. LP3ES, Jakarta.

Ravieq, Zulpurkan, 1987. Pengaruh Perisai Campuran Tanah Mineral. Dolomit dan Tanah Gambut Lokal Sebagai Media Sapih Terhadap Pertumbuhan 
Anakan Eucalyptus alba Reinw. Skripsi Fakultas Kehutanan Unlam. Banjarbaru.

Sudjana, 1985. Desain dan Analisis Eksperiment. Tarsito. Bandung.

Sutedjo, Mul Mulyani, 1994. Pupuk dan Cara Pemupukan. Rineka Cipta Jakarta.

Singarimbun M. 1989. Metode dan Proses Penelitian. Di Dalam : Singarimbun $\mathrm{M}$, Effendi $\mathrm{S}$ (editor). Metode
Penelitian Survei. Edisi Revisi. LP3ES, Jakarta.

Tangkasiang Y.A. 1996. Pengaruh Pemberian Pupuk Kandang dan TSP Terhadap Pertumbuhan Anakan Rotan Taman (Calamus caesius BL) Pada Tanah Aluvial. Skripsi Fakultas Pertanian Universitas PGRI Palangka Raya. Palangka Raya. 